\title{
Coverage, universal access and equity in health: a characterization of scientific production in nursing
}

\author{
Sara Mendoza-Parra ${ }^{1}$
}

\begin{abstract}
Objectives: to characterize the scientific contribution nursing has made regarding coverage, universal access and equity in health, and to understand this production in terms of subjects and objects of study. Material and methods: this was cross-sectional, documentary research; the units of analysis were 97 journals and 410 documents, retrieved from the Web of Science in the category, "nursing". Descriptors associated to coverage, access and equity in health, and the Mesh thesaurus, were applied. We used bibliometric laws and indicators, and analyzed the most important articles according to amount of citations and collaboration. Results: the document retrieval allowed for 25 years of observation of production, an institutional and an international collaboration of $31 \%$ and $7 \%$, respectively. The mean number of coauthors per article was 3.5, with a transience rate of $93 \%$. The visibility index was $67.7 \%$, and $24.6 \%$ of production was concentrated in four core journals. A review from the nursing category with 286 citations, and a Brazilian author who was the most productive, are issues worth highlighting. Conclusions: the nursing collective should strengthen future research on the subject, defining lines and sub-lines of research, increasing internationalization and building it with the joint participation of the academy and nursing community.
\end{abstract}

Descriptors: Universal Coverage; Universal Access to Health Care Services; Equity in Health; Bibliometrics; Nursing.

${ }^{1}$ PhD, Professor, Facultad de Enfermería, Universidad de Concepción, Concepción, Chile.

Mendoza-Parra S. Coverage, universal access and equity in health: a characterization of scientific production in nursing. Rev. Latino-Am. Enfermagem. 2016;24:e2669. [Access ; Available in: DOI: http://dx.doi.org/10.1590/1518-8345.1082.2669. 


\section{Introduction}

Under the assumption that universal health coverage cannot be achieved without scientific data provided by research - therefore, research becomes an undeniable instrument to solve the diversity of questions about how to achieve the universality of care health(1) - the present investigation formulated the following question: What are the characteristics of the nursing contribution in terms of scientific production, subjects and events of interest, regarding coverage, access and universal health equity? Two conceptual references were used to answer this question: universal health coverage and bibliometrics.

Universal coverage or universal health coverage consists of the development of health financing systems that enable all people to have access to health services, including advocacy, prevention, treatment and rehabilitation activities, and that their having access incurs no financial difficulties for them in terms of paying for those services. In other words, it involves solving how the health system is financed, how it protects people from the financial consequences that facing an illness brings to them for the needed care, as well as how the resources available in that system are optimally used ${ }^{(2-3)}$. Thus two other essential concepts arise: access and equity. Universal access in health means an absence of geographic, economic, sociocultural, and organizational or gender barriers, and this is achieved through the progressive removal of barriers that prevent people from using all comprehensive health services, determined equitably and at a national level(4). In turn, universal health equity is a broad, inclusive, and multidimensional concept, consisting of aspects related to achieving good health through processes that not only have to do with the distribution of health care, but also with social justice and non-discrimination in the delivery of such care ${ }^{(5)}$. Health is not only a function of the health sector; in order to achieve it, other factors such as living conditions and working conditions, psychosocial factors and socioeconomic status are involved(6). In other words, universal equity in health means achieving health without any social circumstance to prevent it ${ }^{(5)}$.

Once the conceptual contribution of the study was determined, a bibliometric analysis was used for characterization because, while it allows us to look back at how scientific advances have been achieved and released, it also reveals the generation of useful results and measures the development of scientific disciplines on certain research lines ${ }^{(7)}$. Bibliometric indicators of production quantify both the number of documents published, by country, institution and authors, as well as the citations of those documents as a measure of their impact or importance ${ }^{(8)}$. These are measurements obtained from the statistical analysis of the basic elements of journals or articles with which indicators are built to measure the quality, impact, relationships or collaboration and scientific activity, i.e., the quantification and temporal evolution of the production ${ }^{(9)}$. Thus, the information stored in databases represents raw material which, once analyzed, allows for the extraction of knowledge that can contribute to understanding scientific efforts and making strategic decisions in a particular field of knowledge ${ }^{(10)}$.

Based on the information above, this study had two objectives: first, to characterize the scientific contribution of nursing in coverage, universal access and equity in health through bibliometric indicators; and, second, to understand the trends of this production in terms of studied subjects and phenomena.

\section{Materials and methods}

The type of study and unit of analyze was: bibliometric, descriptive and exploratory research, whose unit of analysis was serial publications and documents recovered from the category, "Nursing", in the Web of Science, henceforth WOS.

Search strategies (Figure 1) were: a consultation of DeCS (Descriptors in Health Sciences) and MeSH (Medical Subject Heading) thesaurus was conducted to recover those controlled terms or descriptors that were related to the natural terms of the research problem, i.e. "coverage", "access" and "equity", and each separately associated with the terms "health", "health care", "health services" and "universal".

\begin{tabular}{|l|c|}
\hline \multicolumn{1}{|c|}{ Descriptor } & Search strategy \\
\hline Cobertura Universal & Universal Coverage \\
\hline Equidad en salud & Equity in Health \\
\hline $\begin{array}{l}\text { Accesibilidad a los Servicios de } \\
\text { Salud }\end{array}$ & Health Services Access \\
\hline Equidad en el acceso & Equity in Access \\
\hline $\begin{array}{l}\text { Acceso universal a servicios de } \\
\text { salud }\end{array}$ & Universal Access to Health \\
\hline $\begin{array}{l}\text { Cobertura de los Servicios de } \\
\text { Salud }\end{array}$ & Health Services Coverage \\
\hline $\begin{array}{l}\text { Cobertura de Servicios Públicos } \\
\text { de Salud }\end{array}$ & State Health Care Coverage \\
\hline $\begin{array}{l}\text { Cobertura de Servicios Privados } \\
\text { de Salud }\end{array}$ & Private Health Care Coverage \\
\hline
\end{tabular}

Figure 1 - Descriptors and search strategies, Nursing Category, Web of Science, 2015 
The universe consisted of: 97 magazines and 410 documents (articles, reviews, letters, notes, editorials, etc.). Data analysis used was: frequency distribution and measures of central tendency and dispersion for exploratory univariate analysis of unidimensional or descriptive bibliometric indicators. For the behavior of authors and journals, the laws of Lotka and Bradford were calculated.

\section{Results}

\section{Document characteristics}

Magnitude, evolution and document types (Figure 2): registration of documents in the wOS starting in the 1990 s, with an article, reaching an average of 47.5 , from 2011 on. By 2015, there were already a total of 410 records. According to the type of documents, in the 25 years studied, $91.5 \%$ (375) were articles, 3.7\% (15) were reviews and $2.2 \%(9)$ were editorials. The rest were brief reports, news, and letters to the editor.

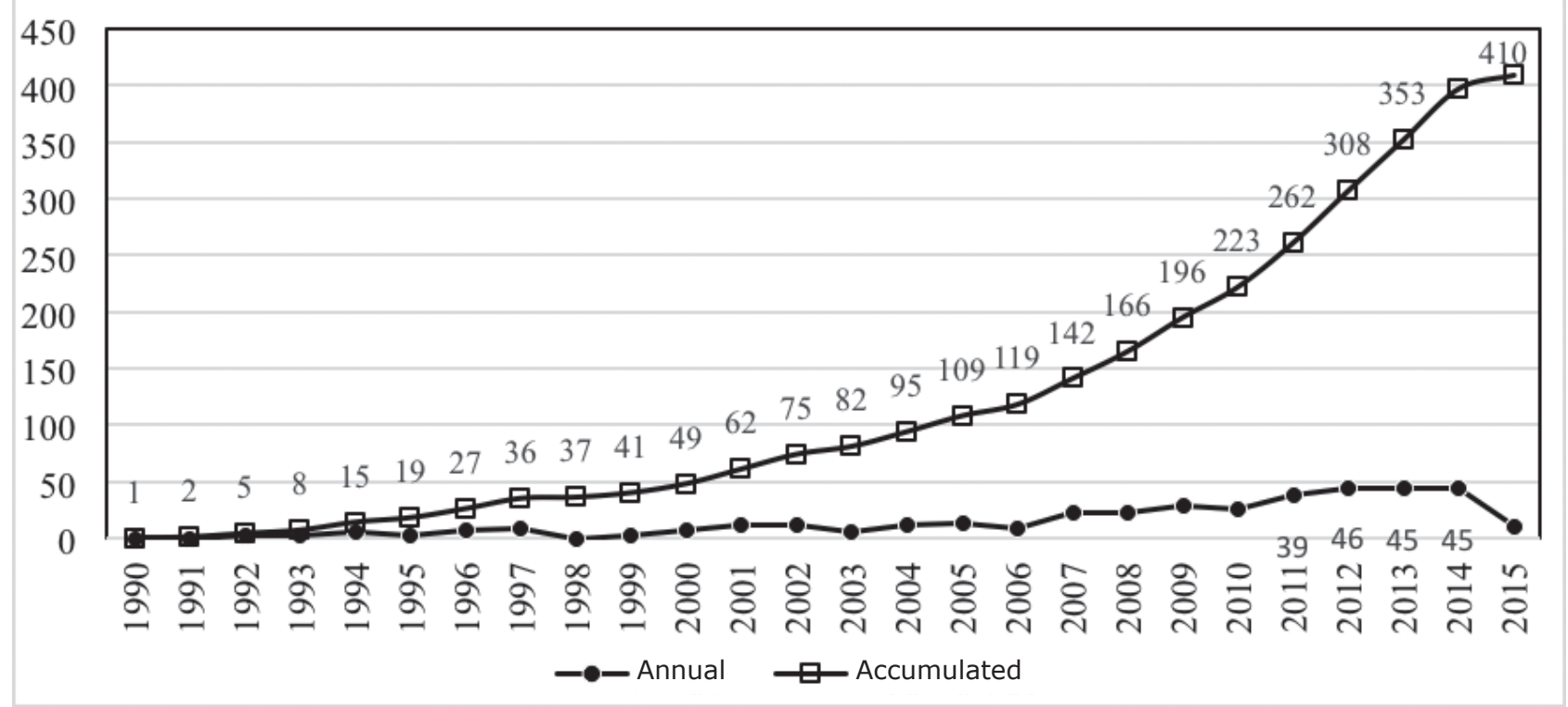

Figure 2 - Scientific production of nurses in subjects on Coverage, Access and Universal Equity in health, Web of Science, $1990-2015(N=410)$.

Collaboration: only $31 \%$ of this production (127) had institutional collaboration; the most common partnership (27) was university/hospital. The rate of collaboration or co-authorship, i.e., the average number of authors per paper, throughout the period was 3.5. The highest value was obtained by a co-authored article from 2007,(11) with 12 Canadian authors, which described how the realtime access that hospital or community nurses had to electronic resources could not only obtain information simultaneously about patient results or about the best evidence to support the practice, but also revealed the close relationship between nursing interventions and patient outcomes. This is a key issue in planning the best interventions in a timely manner, and thereby facilitates access to better health care in the short term ${ }^{(11)}$. Collaboration at a national level exceeded this indicator in $93.4 \%$ of the manuscripts (383), of which, the document with the highest number of authors' participating affiliations was from 2009, in which nine academic Australian philanthropic, research and care institutions were identified; their purpose was to conduct a mapping of rural and regional cancer services in that country. Among other things, significant deficiencies in the provision of oncological services, limited availability of nurses, and significant differences in their training to provide similar care were identified. It was concluded that these deficiencies could contribute to disadvantage the progress of cancer patients living in regional, rural and remote areas, and that it was imperative to take shortterm measures to improve access to better oncological services and thereby eliminate inequalities in the care of these patients in Australia(12). International collaboration only reached $7 \%$, led by the United States, with ten publications along with European, Asian, African and Latin American countries. Notable in this group was a manuscript, with the increased presence of participating countries, with authors from England, Norway, Australia, Switzerland, Germany and Greece. It was a review published in 2013, from 16 studies, describing the perceptions, needs and experiences of pregnant migrant 
women. It was concluded that although all member states of the European Union had ratified resolutions based on human rights, a connection remained between social inequality and barriers to accessing pre-, intraand post-partum care. The results showed that migrant women were a very vulnerable group during pregnancy and childbirth, and it was necessary to improve access to health services to better meet their actual needs ${ }^{(13)}$.

Authors, occasional production and Lotka law: 1197 authors were identified in all of the papers. Of these, 1109 had only one article, so the occasional production or transience rate was $93 \%$. Because of this ratio, we could not get a predictable standard distribution of authors and studies. In accordance with the foregoing, by calculating the Lotka coefficient $(-3.4)$, it was found that the community of authors in regards to coverage, universal access and health equity in the wOS Nursing category remains a community of researchers with poor scientific productivity, represented by an elite group of 34 researchers $(\sqrt{ } 1197)$ who have written three or more papers. Herein, the author Tereza Cristina Scatena Villa stands out, who heads the elite as a co-author of nine articles published from 2011 to 2014, which cover various topics regarding accessibility to tuberculosis care services.

Quotations: visibility index, i.e., the relative weight that had the number of citable documents (articles, reviews, letters and notes), in this case 394, which were cited during the period, was $67.7 \%$ (267). It seemed important to investigate the behavior of scientific citation by scientific category, given that 118 of the citable documents (29.9\%) were linked to one or more of the 18 categories found, other than "Nursing". Table 1 shows the average citation per category. The highest average number of citation (7.7) reached up to six documents, related to the Obstetrics \& Gynecology categories, followed by two related to Public, Environment \& Occupational Health and thirdly, those linked to Cardiology \& Cardiovascular System. The Nursing category, in the 25 years studied, ranked fourth with an average of six citations for 394 documents.

\section{Journal characteristics}

Country of Origin: Table 2 identifies 97 journals originating from 15 countries. Four countries stand out with the largest number of source journals on the subject: USA, England, Brazil and Australia.

Core journals (Bradford Law): based on the number of documents per journal, four Bradford areas were identified (Table 3), each with a production rate ranging between $23 \%$ and $26 \%$. There were five core journals, i.e., those in which the largest scientific production regarding coverage, universal access and equity in health was concentrated: Public Health Nursing from the USA, with 32 documents; Journal of Advanced Nursing from the UK, with 23 documents; Australian Journal of Rural Health with 17 documents; and two Brazilian journals, Revista da Escola de Enfermagem da USP and Acta Paulista de Enfermagem, with 15 and 14 articles, respectively.

Table 1 - scientific categories according to the average number of citations and documents, Nursing Category, Web of Science, 2015

\begin{tabular}{|c|c|c|}
\hline Scientific category & Quote X & Number of quotable documents \\
\hline Obstetrics \& Gynecology & 7.7 & 6 \\
\hline Public, Environmental \& Occupational Health & 7.5 & 51 \\
\hline Cardiovascular System \& Cardiology & 6.8 & 5 \\
\hline Nursing & 6 & 394 \\
\hline Oncology & 5 & 15 \\
\hline Pediatrics & 4.7 & 9 \\
\hline Health Care Sciences \& Services & 4.5 & 13 \\
\hline Psychiatry & 4 & 5 \\
\hline Medical Informatics & 3.6 & 5 \\
\hline Computer Science & 3.6 & 5 \\
\hline Gastroenterology \& Hepatology & 3 & 1 \\
\hline Rehabilitation & 2.9 & 8 \\
\hline Education \& Educational Research & 2.5 & 2 \\
\hline Geriatrics \& Gerontology & 1.2 & 5 \\
\hline Substance Abuse & 1 & 3 \\
\hline Emergency Medicine & 0 & 2 \\
\hline Urology \& Nephrology & 0 & 1 \\
\hline Criminology \& Penology & 0 & 1 \\
\hline Life Sciences \& Biomedicine - Other Topics & 0 & 1 \\
\hline Integrative \& Complementary Medicine & 0 & 1 \\
\hline
\end{tabular}


Table 2 - Distribution of countries of source journals by number of journals and documents, Nursing Category, Web of Science, 2015

\begin{tabular}{lcc}
\hline Country & Number of Journals & Number of Documents \\
\hline USA & 55 & 207 \\
UK & 13 & 73 \\
Brazil & 7 & 32 \\
Australia & 5 & 6 \\
Switzerland & 2 & 4 \\
Spain & 3 & 3 \\
Japan & 1 & 3 \\
Korea & 3 & 2 \\
Scotland & 1 & 2 \\
Portugal & 2 & 1 \\
Colombia & 1 & 1 \\
Cuba & 1 & 1 \\
The Netherlands & 1 & 1 \\
South Africa & 1 & 1 \\
Taiwan & 1 & 410 \\
Total & 97 & 3 \\
\hline
\end{tabular}

Table 3 - Areas of Bradford, concerning coverage, universal access and equity in health, Category Nursing, Web of Science, 2015

\begin{tabular}{ccccc}
\hline $\begin{array}{c}\text { Number of } \\
\text { journals }\end{array}$ & $\begin{array}{c}\text { Number of articles per } \\
\text { journal }\end{array}$ & Accumulated journals, $r$ & $\begin{array}{c}\text { Accumulated articles, } \\
\mathbf{R}(\mathbf{r})\end{array}$ & Bradford Areas \\
\hline 1 & 32 & 1 & 32 & Zone 1 Nucleus \\
5 journals \\
$(24.6 \%)$
\end{tabular}




\section{Study subjects and phenomena}

To monitor trends on topics of interest, it seemed important to retrieve and analyze, by years, the most cited documents separated by scientific categories, and separate from them the phenomena and study subjects (Figure 3). A total of 15 categories in the 394 scientific papers, and 14 citable documents with the highest number of citations by category were identified. In the most cited group, a 2005 review with 286 citations supporting the Nursing category is highlighted.

\begin{tabular}{|c|c|c|c|c|c|}
\hline Year & Citations & Scientific categories & Title & Subjects & Journal \\
\hline 1999 & 15 & Psychiatry & $\begin{array}{c}\text { Utilization of Mental Health Services Among } \\
\text { Rural Elderly }{ }^{(14)}\end{array}$ & Elderly living in rural areas & $\begin{array}{c}\text { Archives of } \\
\text { Psychiatric Nursing }\end{array}$ \\
\hline 2000 & 27 & $\begin{array}{l}\text { Public, Environmental } \\
\text { \& Occupational } \\
\text { Health }\end{array}$ & $\begin{array}{l}\text { The Crisis Nature of Health Care Transitions } \\
\text { for Rural Older Adults }{ }^{(15)}\end{array}$ & $\begin{array}{l}\text { Elderly and their families } \\
\text { living in rural sectors }\end{array}$ & $\begin{array}{l}\text { Public Health } \\
\text { Nursing }\end{array}$ \\
\hline 2002 & 20 & $\begin{array}{l}\text { Oncology / } \\
\text { Health Care Sciences } \\
\text { \& Services }\end{array}$ & $\begin{array}{l}\text { Factors in Making the Decision to Forgo } \\
\text { Conventional Cancer Treatment }{ }^{(16)}\end{array}$ & Cancer patients & Cancer Practice \\
\hline 2005 & 28 & $\begin{array}{l}\text { Obstetrics \& } \\
\text { Gynecology }\end{array}$ & $\begin{array}{l}\text { Factors Influencing Mammography Screening } \\
\text { of Chinese American Women }{ }^{(17)}\end{array}$ & Chinese-American women & $\begin{array}{l}\text { JOGNN-Journal } \\
\text { of Obstetric } \\
\text { Gynecologic and } \\
\text { Neonatal Nursing }\end{array}$ \\
\hline 2005 & 286 & Nursing & $\begin{array}{c}\text { Men and Health Help-Seeking Behavior: } \\
\text { Literature review }{ }^{(18)}\end{array}$ & Men & $\begin{array}{l}\text { Journal of advanced } \\
\text { nursing }\end{array}$ \\
\hline 2007 & 17 & $\begin{array}{l}\text { Cardiovascular } \\
\text { System \& Cardiology }\end{array}$ & $\begin{array}{l}\text { Telehealth as a Tool for Enhancing Care for } \\
\text { Patients With Cardiovascular Disease }{ }^{(19)}\end{array}$ & Cardiovascular patients & $\begin{array}{l}\text { Journal of } \\
\text { Cardiovascular } \\
\quad \text { Nursing }\end{array}$ \\
\hline 2008 & 27 & $\begin{array}{l}\text { Public, Environmental } \\
\text { \& Occupational } \\
\text { Health }\end{array}$ & $\begin{array}{c}\text { Experiences of Homeless People in the } \\
\text { Health Care Delivery System: a Descriptive } \\
\text { Phenomenological Study }{ }^{(20)}\end{array}$ & Homeless adults & $\begin{array}{l}\text { Public Health } \\
\text { Nursing }\end{array}$ \\
\hline 2008 & 16 & Pediatrics & $\begin{array}{l}\text { Child Morbidity and Care-Seeking in Nairobi } \\
\text { Slum Settlements: the Role of Environmental } \\
\text { and Socio-Economic Factors }{ }^{(21)}\end{array}$ & Kids in the urban districts & $\begin{array}{l}\text { Journal of Child } \\
\text { Health Care }\end{array}$ \\
\hline 2008 & 14 & $\begin{array}{l}\text { Computer Science } \\
\text { Medical Informatics }\end{array}$ & $\begin{array}{l}\text { Evaluation of Patient Satisfaction With Tailored } \\
\text { Online Patient Education Information }\end{array}$ & $\begin{array}{l}\text { Patients with internet } \\
\text { access }\end{array}$ & $\begin{array}{l}\text { CIN-Computers } \\
\text { Informatics Nursing }\end{array}$ \\
\hline 2008 & 3 & $\begin{array}{l}\text { Gastroenterology \& } \\
\text { Hepatology }\end{array}$ & $\begin{array}{l}\text { Reducing the Incidence of Colorectal Cancer } \\
\text { in African Americans }{ }^{(23)}\end{array}$ & $\begin{array}{l}\text { African American cancer } \\
\text { patients }\end{array}$ & $\begin{array}{l}\text { Gastroenterology } \\
\text { Nursing }\end{array}$ \\
\hline 2008 & 5 & $\begin{array}{l}\text { Education \& } \\
\text { Educational Research }\end{array}$ & $\begin{array}{l}\text { Student Nurses' Attitudes to Vulnerable } \\
\text { Groups: a Study Examining the Impact of a } \\
\text { Social Inclusion Module }{ }^{(24)}\end{array}$ & Nursing students & $\begin{array}{l}\text { Nurse Education } \\
\text { Today }\end{array}$ \\
\hline 2008 & 2 & Substance Abuse & $\begin{array}{c}\text { Health Status and Access to Care for } \\
\text { Homeless Adults With Problem Alcohol and } \\
\text { Drug Use }{ }^{(25)}\end{array}$ & Homeless adults & $\begin{array}{c}\text { Journal of } \\
\text { Addictions Nursing }\end{array}$ \\
\hline 2011 & 12 & Rehabilitation & $\begin{array}{l}\text { Exploring Women's Knowledge, Experiences } \\
\text { and Perceptions of Cervical Cancer Screening } \\
\text { in an Area of Social Deprivation }{ }^{(26)}\end{array}$ & $\begin{array}{l}\text { Women in socially deprived } \\
\text { areas }\end{array}$ & $\begin{array}{l}\text { European Journal of } \\
\text { Cancer Care }\end{array}$ \\
\hline 2013 & 3 & $\begin{array}{l}\text { Geriatrics \& } \\
\text { Gerontology }\end{array}$ & $\begin{array}{l}\text { Building and Testing a Patient-Centric } \\
\text { Electronic Bedside Communication Center } \\
\text { (27) }\end{array}$ & $\begin{array}{l}\text { Inpatient adults and their } \\
\text { families }\end{array}$ & $\begin{array}{l}\text { Journal of } \\
\text { Gerontological } \\
\text { Nursing }\end{array}$ \\
\hline
\end{tabular}

Figure 3 - Summary of documents related to coverage, universal access and equity in health, by years, citations, subject and journal, Nursing Category, Web of Science, 2015

In the UK, based on growing American evidence that men seek help to solve several health problems, such as depression, substance abuse, physical disabilities or stressful life events less frequently than women and that men were more reluctant to seek help and access health services, there was a need to retrieve scientific literature to describe such behavior. A growing number of gender studies were found that showed a tendency for men to delay seeking help when they got sick. Under this approach, white middle-class men, for example, had a traditional male behavior that prevented them from accessing timely health care. It was concluded that, primarily, the role of male beliefs and the similarities and differences between different male profiles required more attention and research; especially taking into account health inequalities that existed between men of different socio-economic status and ethnicity. The authors suggested further research with heterogeneous samples to obtain a better understanding of the triggers and barriers associated with the process of making decisions about men 
seeking care health. They emphasized that, with more evidence, not only could it improve the access of men to health care, but it would also improve the quality of life of the women who informally have to take over that care, and therefore also reduce national health costs associated with delayed health care ${ }^{(18)}$.

\section{Discussion and conclusions}

It is worth highlighting that the entry of Scielo and $\mathrm{KCI}$-Korean collections in the Web of Science enables the performance of global bibliometric studies, in order to observe the behavior of particular scientific fields and study phenomena. While it is arguable that this study does not include everything the nursing community has produced regarding coverage, access and universal equity in health, from WOS, we can separate the collection of documents with the best scientific quality about the subject, and have an overview of their contribution.

With respect to documents, specifically regarding the evolution of magnitude, it is clearly shown that the issue has not entered the phase of linear growth. This is a characteristic that lends to investigative work with a scientific maturity of an area of knowledge, even if the 25-year period studied was enough to strengthen this line of research. Evidence that reinforces this includes the small amount of retrieved reviews (3.7\%) and primarily national collaboration (93.4\%) which originated from the university environment with high levels of transience. This coincides with the point made by Trzesniak(28) to establish that nursing, as with other emerging sciences, is still in transition from technology/profession into science/research, and the behavior of the group that has researched coverage, access and equity in health, proves it.

It is remarkable that, despite the increased productivity originating in countries such as the USA and UK, it is a Brazilian author that leads the productivity rates by author. Indeed, Scatena Villa has had a continuing involvement over time with nine articles that may well represent a research subline regarding coverage, access and equity in patients with tuberculosis.

The visibility achieved by the citable documents $(67 \%)$ is also important, and almost $30 \%$ are categorized in other scientific fields, indicating that those papers produced by Nursing on the issue not only impact its own group, but also contribute to the knowledge of other scientific areas(9)

Regarding the journals, it is expected that countries with a lot of data in the WOS occupy the greatest amount of indexed journals, which makes it more relevant that
Brazil is integrated into the group of core journals, and ranks third with seven journals which accumulate 72 full text documents with free access. No doubt, this free access incorporated into a global database such as the wOS could be called global scientific accessibility. This is a key and important feature in order to ethically meet universal health coverage. Without access to relevant science produced around the world, one cannot speak of universality or coverage or access, and, even less, of equity in health.

Regarding the featured articles, either in collaboration or citations, the set of documents indicates that nursing has understood very well the concepts of coverage, access and universal equity in health. The fact that the study subjects are elderly in rural areas, cancer patients, patients with psychiatric illnesses, pregnant migrant women, homeless adults, children living in slums, adult men hospitalized or unwilling to access health care, and many other types of groups, reflects an understanding of the need to progressively remove all barriers that prevent people from using the comprehensive health services, organized by the countries to which they belong(29). Likewise, the fact that the research phenomena most frequently cited related to decision-making in health, use of health services, factors affecting diagnostics, mean usage, user satisfaction, attitudes of nursing students confronting vulnerable groups, or use of computer networks and tools to educate or connect the family with the inpatient, indicate that nursing seeks, through its research, those niches of inequality and inequity in care as a mechanism to clearly observe reality and reduce those gaps that impede universality in health care.

Although neither the methodological framework nor the theoretical research in the study were part of this investigation, we observed a variety of qualitative and quantitative approaches to solve research problems, and the gender perspective as a fundamental perspective to build knowledge in this area. Gender and universal coverage, access and equity in health care perspectives have their fundamental livelihood in human rights and ethics.

It is a fact that the worldwide nursing community already has core journals in the area, but there remains a need to strengthen future research by better organizing it in terms of research lines and sub lines, internationalization, and creating a close link between academia, now linked to nursing, which is developed at a community level. 


\section{References}

1. Organización Mundial de la Salud (OMS). Informe sobre la salud en el mundo 2013: Investigaciones para una cobertura universal de salud. [Acesso 1 maio 2015]. Disponível em: http://apps.who.int/iris/ bitstream/10665/85763/1/9789240691223_spa.pdf

2. Organización Mundial de la Salud (OMS). Resumen Informe sobre la salud en el mundo 2010: La financiación de los sistemas de salud el camino hacia la cobertura universal. [Acesso1 maio 2015]. Disponível em: http:// www.who.int/whr/2010/10_summary_es.pdf?ua=1

3. World Health Organization (WHO). Fiftyeighth World Health Assembly: Sustainable health financing, universal coverage and social health insurance. Geneva, 16-25 May 2005. Resolution WHA58.33. [Acesso 10 maio 2015]. Disponível em: http://apps._who.int/gb/ ebwha/pdf_files/WHA58/WHA58_33-en.pdf

4. Organización Mundial de la Salud (OMS). 66a Sesión del Comité Regional de la OMS para Las Américas Washington. CD53/5, Rev. 2: Estrategia para el acceso universal a la salud y la cobertura universal de salud. [Acesso 17 maio 2015]. Disponível em: http://www. paho.org/HQ/index.php?option=com_content\&view $=$ a rticle\&id=9774:53rd-directing-council\&Itemid $=41062$ \&lang=es\#InformeFinal.

5. Sen A. ¿Porqué la equidad en salud?. Rev Panam Salud Publica. 2002;11(5/6):302-9.

6. Bachellet M. Hacia una cobertura universal de salud: aplicación de una perspectiva de género. MEDICC Rev. 2015;17(1):19-20.

7. Sanz-Valero J, Tomás Casterá V, Wanden-Berghe C. Estudio bibliométrico de la producción científica en el período de 1997 a 2012. Rev Panam Salud Publica. 2014;35(2):81-8.

8. De Arenas J, Santillan-Rivero E. Bibliometría ¿para qué?. Nueva Epoca. 2002;5(1):3-10.

9. Mendoza-Parra S, Paravic-Klijn T, Muñoz-Muñoz AM, Barriga O, Jimenez-Contreras, E. Visibility of Latin American Nursing Research (1959-2005). J Nurs Scholarsh. 2009;41(1):54-63.

10. Castiel L, Sanz-Valero J. Política científica: manejar la precariedad de los excesos y desnaturalizar la ideología "publicacionista" todopoderosa. [Editorial]. Salud Colect. 2009;5(1):5-11.

11. Doran DM, Mylopoulos J, Kushniruk A, Nagle L, Laurie-Shaw B, Sidani $S$, et al. Evidence in the palm of your hand: development of an outcomes-focused knowledge translation intervention. Worldviews Evid Based Nurs. 2007;4(2):69-77.

12. Underhill C, Bartel R, Goldstein D, Snodgrass H, Begbie $\mathrm{S}$, Yates $\mathrm{P}$, et al. Mapping Oncology Services in Regional and Rural Australia. Aust J Rural Health. 2009;17(6):321-9
13. Balaam MC, Akerjordet K, Lyberg A, Kaiser B, Schoening $E$, Fredriksen AM, et al. A Qualitative Review of Migrant Women's Perceptions of Their Needs and Experiences Related to Pregnancy and Childbirth. J Adv Nurs. 2013;69(9):1919-1930.

14. Neese J, Abraham I, Buckwalter K. Utilization of Mental Health Services Among Rural Elderly. Arch Psychiatr Nurs. 1999;13(1):30-40.

15. Magilvy J, Congdon J. The Crisis Nature of Health Care Transitions for Rural Older Adults. Public Health Nurs. 2000;17(5):336-45.

16. Verhoef M, White M. Factors in Making the Decision to Forgo Conventional Cancer Treatment. Cancer Pract. 2002;10(4):201-7.

17. $\mathrm{Yu}$ M, Wu T. Factors Influencing Mammography Screening of Chinese American Women. JOGNN. 2005;34(3):386-94.

18. Galdas $P$, Cheater F, Marshall P. Men and Health Help-Seeking Behaviour: Literature Review. J Adv Nurs. 2005;49(6):616-23.

19. Artinian N. Telehealth as a Tool for Enhancing Care for Patients With Cardiovascular Disease. J Cardiovasc Nurs. 2007;22(1):25-31.

20. Martins D. Experiences of Homeless People in the Health Care Delivery System: a Descriptive Phenomenological Study. Public Health Nurs. 2008;25(5):420-30.

21. Ndugwa R, Zulu E. Child Morbidity and Care-Seeking in Nairobi Slum Settlements: the Role of Environmental and Socio-Economic Factors. J Child Health Care. 2008;12(4):314-28.

22. Atack L, Luke $R$, Chien $E$. Evaluation of Patient Satisfaction With Tailored Online Patient Education Information. Cin-Comput Inform Nurs. $2008 ; 26(5): 258-64$.

23. Hamlyn S. Reducing the Incidence of Colorectal Cancer in African Americans. Gastroenterol Nurs. 2008;31(1):39-42.

24. Wray J, Walker L, Benedict. Student Nurses' Attitudes to Vulnerable Groups: a Study Examining the Impact of a Social Inclusion Module. Nurse Educ Today. 2008;28(4):513-20.

25. Savage C, Gillespie G, Lindsell C. Health Status and Access to Care for Homeless Adults With Problem Alcohol and Drug Use. J Addict Nurs. 2008;19(1):27-33. 26. Logan L, Mcilfatrick S. Exploring Women's Knowledge, Experiences and Perceptions of Cervical Cancer Screening in an Area of Social Deprivation. Eur J Cancer Care. 2011;20(6):720-7.

27. Dykes P, Carroll D, Hurley A, Benoit A, Chang F, Pozzar $\mathrm{R}$ et al. Building and Testing a Patient-Centric Electronic Bedside Communication Center. J Gerontol Nurs. 2013;39(1):15-9. 
28. Trzesniak P. Conferências com o espírito Solvay em áreas cientificamente emergentes: um impulso notável para a construção de conhecimento. Rev Esc Enferm USP. 2015;49(2):184-6.

29. De Bortoli SH. Strategy for universal access to health and universal health coverage and the contribution of the International Nursing Networks. Editorial. Rev. Latino-Am. Enfermagem. 2014;22(6):891-2.

Barrio Universitario

Concepción, Región del Bío-Bío, Chile

E-mail: smendoza@udec.cl

Copyright $\odot 2016$ Revista Latino-Americana de Enfermagem This is an Open Access article distributed under the terms of the Creative Commons (CC BY).

This license lets others distribute, remix, tweak, and build upon your work, even commercially, as long as they credit you for the original creation. This is the most accommodating of licenses offered. Recommended for maximum dissemination and use of licensed materials. 